DOI: 10.19112/2413-6174-2021-S1-27

\title{
ИЗМЕНЕНИЕ СОДЕРЖАНИЯ ХЛОРОФИЛЛА В ПОБЕГАХ ПШЕНИЦЫ ПОД ДЕЙСТВИЕМ РАЗЛИЧНЫХ ФОРМ ЖЕЛЕЗА
}

\author{
Е.А. Осипова ${ }^{1 *}$, С.В. Лебедев ${ }^{1,2}$ \\ ${ }^{1}$ Оренбургский государственный университет,460018, г. Оренбург, просп. Победы, д. 13 \\ ${ }^{2}$ ФГБНУ «Федеральный научный центр биологических систем и агротехнологий Российской академии наук», \\ 460000, Оренбургская область, г. Оренбург, ул. 9 Января д. 29 \\ *e-mail: kudryavceva.elen@ mail.ru
}

РЕЗЮМЕ. Целью настоящего исследования явилось определение содержания хлорофилла в побегах пшеницы, произрастающих под действием различных форм железа ( $\mathrm{Fe}^{0}$ (80 \pm 5 нм), $\mathrm{Fe}_{3} \mathrm{O}_{4}$ (ширина 50-80 нм, высота 4-10 нм), $\left.\mathrm{FeSO}_{4} \cdot 7 \mathrm{H}_{2} \mathrm{O}, \mathrm{Fe}_{2}\left(\mathrm{SO}_{4}\right)_{3} \cdot 9 \mathrm{H}_{2} \mathrm{O}\right)$. Экстракцию пигментов проводили 96\%-ным этиловым спиртом на 7-й день, концентрацию хлорофиллов рассчитывали по уравнениям Вернона. Максимальный синтез хлорофилла $a$ и $b$ был характерен для ионных форм железа в концентрации $1 \cdot 10^{-3}$ г/л, наночастиц железа $1 \cdot 10^{-4}$ г/л и магнетита $\mathrm{Fe}_{3} \mathrm{O}_{4}$ при концентрации $1 \cdot 10^{-6}$ г/л. Отношение хлорофилла $a$ к хлорофиллу $b$ в надземной части пшеницы на 7-й день соответствует норме при использовании наночастиц железа $\mathrm{Fe}^{0}$ и ионных форм двухвалентного железа в виде сульфата $\mathrm{FeSO}_{4}$. По мере увеличения концентрации наночастиц магнетита повышается концентрация хлорофилла $a$, а при достижении максимальной концентрации до $1 \cdot 10^{-3}$ г/л увеличивается количество хлорофилла $b$, на фоне уменьшения соотношения $a / b$. Таким образом, наночастицы железа $\mathrm{Fe}^{0}$ и водный раствор сульфата железа (II) способствуют формированию фотосинтетического аппарата с интенсивным фотосинтезом.

КЛЮЧЕВЫЕ СЛОВА: пшеница, наночастицы, железо, магнетит, сульфат железа, хлорофилл.

\section{VARIATION IN THE CONTENT OF CHLOROPHYLL IN WHEAT UNDER THE INFLUENCE OF VARIOUS FORMS OF IRON}

\author{
E.A. Osipova ${ }^{1 *}$, S.V. Lebedev ${ }^{1,2}$
}

${ }^{1}$ Orenburg State University, 13, Pobedy ave, Orenburg, Russia, 460018

${ }^{2}$ FSSI "Federal Research Center of Biological Systems and Agro-technologies of the Russian Academy of Sciences", 29, 9 January St., Orenburg, Russia, 460000

*e-mail: kudryavceva.elen@mail.ru

ABSTRACT. The purpose of this study was to determine the content of chlorophyll in wheat scions growing under the influence of various forms of iron $\left(\mathrm{Fe}^{0}(80 \pm 5 \mathrm{~nm}), \mathrm{Fe}_{3} \mathrm{O}_{4}\right.$ (width $50-80 \mathrm{~nm}$, height $\left.4-10 \mathrm{~nm}\right), \mathrm{FeSO}_{4} \cdot 7 \mathrm{H}_{2} \mathrm{O}$, $\left.\mathrm{Fe}_{2}\left(\mathrm{SO}_{4}\right)_{3} \cdot 9 \mathrm{H}_{2} \mathrm{O}\right)$. The pigments were extracted using $96 \%$ ethyl alcohol on day 7 ; the chlorophyll concentration was calculated using the Vernon equations. The maximum synthesis of chlorophyll a and b was typical for iron ionic forms at a concentration by $1 \cdot 10^{-3} \mathrm{~g} / \mathrm{l}$ and iron nanoparticles at a concentration by $1 \cdot 10^{-4} \mathrm{~g} / \mathrm{l}$, and $\mathrm{Fe}_{3} \mathrm{O}_{4}$ magnetite at a concentration of $1 \cdot 10^{-6} \mathrm{~g} / \mathrm{l}$. The ratio of chlorophyll a to chlorophyll $\mathrm{b}$ in the terrestrial part of wheat on day 7 corresponds to the norm using iron nanoparticles $\mathrm{Fe}^{0}$ and ferrous iron ions in the form of $\mathrm{FeSO}_{4}$. As the concentration of magnetite nanoparticles increases, the concentration of chlorophyll a increases, and when the maximum concentration amount $\cdot 10^{-3} \mathrm{~g} / \mathrm{l}$, the amount of chlorophyll $b$ rise, while the $a / b$ ratio decreases.In such a way, iron $\mathrm{Fe}^{0}$ nanoparticles and an aqueous solution of iron (II) sulfate contribute to the formation of a photosynthetic apparatus with intensive photosynthesis.

KEYWORDS: wheat, nanoparticles, iron, magnetite, iron sulfate, chlorophyll.

\section{ВВЕДЕНИЕ}

Дефицит железа приводит к хлорозу листьев, которое снижает продуктивность культурных растений и ведет к их гибели. Внесение в почву соединений железа не приводит к ожидаемому эффекту, что связано с быстрым его переходом в окисленную, недоступную для растений форму. Для решения данной проблемы возможно использование наночастиц, что требует тщательного изучения. 


\section{МАТЕРИАЛЫ И МЕТОДЫ}

Семена растения Triticum vulgare Vill, выращивали в водной среде с различной концентрацией наночастиц железа $\mathrm{Fe}^{0}$ и магнетита $\mathrm{Fe}_{3} \mathrm{O}_{4}$ в сравнении с воздействием водных растворов $\mathrm{FeSO}_{4}$, $\mathrm{Fe}_{2}\left(\mathrm{SO}_{4}\right)_{3}$. Концентрацию хлорофиллов рассчитывали по уравнениям Вернона после экстракции 96\%ным этиловым спиртом.

Статистическую обработку полученных данных проводили с использованием программы Excel общепринятыми методами вариационной статистики.

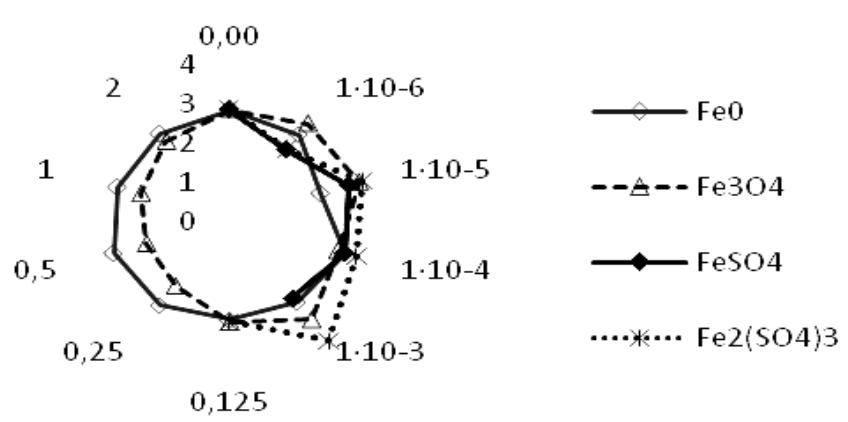

Рисунок. Отношение хлорофилла а к хлорофиллу в в надземной части пшеницьь

\section{РЕЗУЛЬТАТЫ И ОБСУЖДЕНИЕ}

На 7-й день количество хлорофиллов $a$ и $b$ во всех опытах увеличивается относительно контроля, так как железо входит в состав ферментов, ускоряющих реакции синтеза хлорофилла. О степени сформированности фотосинтетического аппарата судили по отношению хлорофилла $a$ к хлорофиллу $b$, в норме этот показатель должен находится в интервале от 2,2 до 3,0 (Титова, 2010) (рисунок).

\section{ВЫВОДЫ}

Наночастицы железа $\mathrm{Fe}^{0}$ и водный раствор сульфата железа (II) способствуют формированию фотосинтетического аппарата с интенсивным фотосинтезом.

\section{Сиисок литературы / References}

1. Титова М.С. Содержание фотосинтетических пигментов в хвое Picea Abies и Picea koraiensis. Вестник ОГУ. 2010; 1: 9-12. [Titova M.S. Content of photosynthetic pigments in needles of Picea Abies and Picea Koraiensis. VESTNIK OSU. 2010 ; 12 : 9-12. (in Russ.)]. 